\title{
The Professional Competences of Physical Education Teachers from North-Eastern Italy
}

Miloš Tul ${ }^{1}$, Bojan LeskošEK ${ }^{2}$ And MaRjeta KovaČ ${ }^{\star 3}$

$\approx$ This cross-sectional study was designed to evaluate the self-perceived professional competences of Italian physical education (PE) teachers. For this purpose, a self-administered questionnaire has been designed to examine a broad scope of general and subject-specific competences. The participants, 484 Italian PE teachers from the north-eastern part of Italy, evaluated their professional competences on a four-level Likert scale. Factor analysis is used for the examination of the internal structure of the competence field. The results show that the self-perception of their competence profile was quite complex, consisting of 13 factors, which together explain $51.1 \%$ of the total variance. Didactic approaches, which represent the first factor and explain $31.3 \%$ of the total variance, seem to be the most informative for their estimations of how effectively they can teach their specific subject. The teachers feel insufficiently competent in some general areas, such as the use of information and communications technology, communication in foreign language, scientific research work, initiative, and entrepreneurial spirit. They do not have sufficient abilities to bring to $\mathrm{PE}$ the recent sports activities in which teenagers currently participate in their free time. The outcomes of the present study may aid in the future updating of PE teacher education study programmes and the designing of a creative system of lifelong training programmes.

Keywords: physical education, teachers, professional areas, perceived competences

1 State scientific high school of France Prešeren, Italy.

2 Department of Natural Sciences, Faculty of Sport, University of Ljubljana, Slovenia.

$3{ }^{\star}$ Corresponding Author. Department of Pedagogic and Didactic, Faculty of Sport, University of Ljubljana, Slovenia; Marjeta.Kovac@fsp.uni-lj.si. 


\section{Poklicne kompetence učiteljev športne vzgoje iz severovzhodne Italije}

Miloš Tul, Bojan LeskošEK In Marjeta Kovač

$\propto$ Namen študije je bil ugotoviti, kako italijanski učitelji športne vzgoje zaznavajo svojo strokovno usposobljenost. Uporabljen vprašalnik je vključeval sklopa splošnih in predmetnospecifičnih kompetenc. Anketiranci, 484 italijanskih učiteljev športne vzgoje iz severovzhodne Italije, so ocenili svojo strokovno usposobljenost na štiristopenjski lestvici. Za preučitev notranje strukture učiteljevega kompetenčnega prostora je bila uporabljena faktorska analiza. Ugotavljamo, da je kompetenčni profil učitelja športne vzgoje zelo kompleksen, saj ga sestavlja 13 faktorjev, ki pojasnjujejo 51,1 \% skupne variance. Kot najpomembnejše so se izkazale predmetnospecifične kompetence, ki predstavljajo prvi faktor, poimenovan didaktični pristopi. Ta pojasnjuje 31,3\% skupne variance in tako najbolj opredeljuje učinkovitost poučevanja športne vzgoje. Na nekaterih splošnih področjih, kot so: uporaba informacijske in komunikacijske tehnologije, sporazumevanje v tujem jeziku, znanstvenoraziskovalno delo, dajanje pobud in podjetniški duh, se učitelji zaznavajo kot premalo kompetentne. Prav tako niso dovolj usposobljeni za vključevanje sodobnih vrst športa, s katerimi se ukvarjajo današnji najstniki v svojem prostem času, v pouk športne vzgoje. Izsledki študije lahko pomagajo pri posodabljanju študijskih programov bodočih učiteljev športne vzgoje in nudijo iztočnice za oblikovanje programov stalnega strokovnega spopolnjevanja.

Ključne besede: športna vzgoja, učitelji, poklic, zaznava kompetenc 


\section{Introduction}

Teachers and their competences, in particular, are attributed a crucial role in fulfilling quality education; therefore, teacher training and lifelong learning programmes should be included among the priority political tasks of European countries (OECD, 2009; Peklaj, 2015).

A competence is described as a complex combination of knowledge, skills, understanding, values, attitudes, and desires that leads to effective, embodied human action in a particular domain (Deakin Crick, 2008). Within the Tuning Educational Structures in Europe project, through policies aimed to create an integrated higher education area in Europe, the 30 most relevant general competences have been described and divided into three wider categories: instrumental or practical competences, interpersonal competences, and systemic competences (Gonzalez \& Wagenaar, 2003).

In the field of education, competences can be divided into general (universal or subject-independent) and specific ones (Eurydice, 2002); both types should be transferable and available for use in various situations, not solely in the context in which they were acquired. General competences are related to communication, teamwork, the ability to acquire and transfer knowledge, and lifelong learning, while specific competences are related to individual teaching subjects (Eurydice, 2003).

Recently, five new areas of teachers' competences have been identified: teaching with the use of modern educational technology, integration of children with special needs, working with culturally mixed groups of children, management of schools with various administrative tasks, and conflict management (Eurydice, 2003). When modernising study programmes, which was carried out in parallel with the Bologna reform in the majority of European countries, the Directorate for Education and Culture of the European Commission (2005) defined common European principles for teachers' competences as guidelines, which should be adhered to by the creators of educational policies on national and regional levels: the profession of a teacher should be based on a high degree of education, it should be included in a lifelong learning framework, it should be mobile, and it should be based on partnership. In studying and defining the competences of teachers of individual subjects, Laporte (1997) emphasised the importance of a common (i.e., European) approach to physical education (PE), which included uniform concepts and PE teacher education (PETE) programmes. Between 2002 and 2007, the sport-related AEHESIS (Aligning a European Higher Education Structure in Sport Science), a thematic network project, focussed on the systematisation and professionalisation of vocations 
in the field of sport, particularly the profession of the PE teacher and his/her competences (Hardman, Klein, Patriksson, Rychtecky, \& Da Costa, 2008). The AEHESIS project proposed and framed the core sets of principles for PETE programmes and their benchmark standards, which should embrace learning outcomes and occupational competences, i.e., what a teacher should know and be able to do (Hardman et al., 2008). Nevertheless, when talking about educational affairs in Europe in general, the responsibility for education is still fully regulated on the national levels.

The competences of Italian PE teachers have been studied by Vitali and Spoltore (2010). Their study had some significant limitations: the sample was small $(\mathrm{n}=37)$, and included students from sports and motoric sciences, PE teachers (five years after graduation) and other workers from the sport labour market. Furthermore, it should be noted that there are no special study programmes exclusively for PE teachers in Italy (Mussino, Cini, \& Talucci, 2005). A step towards a realistic assessment of the effectiveness of the different PETE programmes in Italy is to assess the PE teachers' self-evaluations of their teaching competences. By determining how they perceive their current competences, we can certainly locate some problems in practice that could be resolved by improving the PETE programmes and providing appropriate PE teacher lifelong learning programmes. Thus, the study used a purpose-designed questionnaire to examine their self-perception of general and subject-specific competences.

\section{Methods}

\section{Sample}

The sample consisted of 484 PE teachers (209 men, 43.2\%; 275 women, $56.8 \%$ ) from the north-eastern part of Italy; 196 (40.5\%) participants were employed at lower secondary schools, 244 (50.4\%) participants at upper secondary schools, and the remaining participants were employed elsewhere (primary schools, project work). Almost two thirds of participants had been teaching more than 20 years $(n=338,69.8 \%)$; the remaining participants are almost equally distributed in the following groups: from 11 to 20 years of working experience $(n=68,14 \%)$ and up to 10 years of working experience $(n=78,16.1 \%)$. Most of the participants $(n=402,83.1 \%$ ) had finished a three-year university PETE programme at a higher school for PE (it. Istituto Superiore di Educazione Fisica). 


\section{Instrument}

According to previous studies (Gallardo, 2006; Hardman et al., 2008; Kovač, Sloan, \& Starc, 2008; Laporte, 1999), a self-administered questionnaire was constructed for the study. It consisted of three parts: 1) demographic (gender, length of work experience, age, teaching level), 2) general competences (36 items), and 3) specific competences (40 items).

General competences included the abilities to communicate, to work on a team, to lead teams, to plan and adapt the teaching process, to understand general pedagogic and didactic principles, to use information and communications technology (ICT), to communicate in a foreign language, to mentor; to follow safety principles, and to behave ethically and responsibly.

Specific competences included specific aspects of PE, such as understanding the social, biological, and physiological aspects of physical activity (PA) and sport; understanding the theory of training; possessing pedagogic skills and didactic abilities related to teaching PE in the narrow (demonstration of motor skills and methodical steps) and broad senses of the word (crosscurriculum issues, ICT use, evaluation of the teaching process).

The self-perception of their current level of competences was reported on a four-level Likert scale with ' 1 ' indicating the lowest perception of competence and ' 4 ' the highest.

\section{Data Collection Method}

The questionnaire was sent to all lower $(n=807)$ and upper $(n=310)$ secondary schools in the regions of Friuli-Venezia Giulia and Veneto by regular mail. PE teachers were informed about the objectives of the study as well as the voluntary and anonymous nature of their participation. A total of 495 questionnaires was returned; eleven of them were missing more than three pieces of data and were thus excluded from the study. Questionnaires with 1 to 3 pieces of data missing ( $\mathrm{n}=87,17.6 \%$ ) had the missing data imputed with the use of an E-M algorithm. In the end, 484 questionnaires were included in the analysis.

According to data from the Regional School Office of Trieste, in 2011 approximately 1,879 PE teachers were working in secondary schools of both levels in Friuli-Venezia Giulia and Veneto. The sample represented approximately $28 \%$ of the entire population of PE teachers in both regions. 


\section{Data Analysis}

The data were analysed with the PASW Statistics 18.0 computer programme. First, the Kaiser-Meyer-Olkin test (KMO) was used to evaluate the adequacy of the sample of variables. Second, the Bartlett test of sphericity was used. To reduce the complexity of connections between questionnaire items, maximum likelihood (ML) factor analysis with oblique rotation (Direct oblimin) was used. Kaiser criterion $(\lambda>1)$, scree plot, and the interpretability of factors were considered when deciding on the number of factors. Cronbach's alpha coefficient of internal consistency was used to calculate the reliability of the questionnaire.

\section{Results}

The entire questionnaire has a high degree of reliability (Cronbach's alpha $=.97)$, while the values of individual segments of the questionnaire vary between .77 and .90 . The results of the Kaiser-Meyer-Olkin test (KMO = .96) and the Bartlett test $(\mathrm{p}<.005)$ confirmed the eligibility of factor analysis. The procedure extracted 13 factors, which together explain $51.1 \%$ of the total variance (Table 1).

\section{Table 1}

Factor names, Average Values, and Standard Deviation of Individual Items, Factor Loadings, Cronbach's Alpha, and Proportion of the Total Variance Explained by Individual Factor

\begin{tabular}{|c|c|c|c|c|c|}
\hline Factor / Item & I & $\bar{x}$ & s & $\alpha$ & $\% \mathbf{v}$ \\
\hline \multicolumn{6}{|l|}{ 1. Didactic approaches } \\
\hline $\begin{array}{l}\text { Qualification for encouraging creativity in finding solutions to motor } \\
\text { tasks }\end{array}$ & .59 & 2.96 & .70 & \multirow{7}{*}{.89} & \multirow{7}{*}{31.34} \\
\hline $\begin{array}{l}\text { Qualification for encouraging student's learning in an instructive and } \\
\text { creative way }\end{array}$ & .58 & 3.11 & .66 & & \\
\hline Qualification for encouraging students to be sport active in free time & .55 & 3.21 & .68 & & \\
\hline Qualification for encouraging personal progress of a student & .45 & 3.17 & .62 & & \\
\hline Qualification for formation and conveying of feedback information & .39 & 3.15 & .68 & & \\
\hline Qualification for special pedagogic approaches & .35 & 2.67 & .77 & & \\
\hline $\begin{array}{l}\text { Qualification for different ways of assessment and grading knowledge } \\
\text { in PE }\end{array}$ & .32 & 3.04 & .68 & & \\
\hline
\end{tabular}




\begin{tabular}{lllllll}
\hline Factor / Item & I & $\bar{x}$ & $s$ & $\alpha$ & $\% v$ \\
\hline
\end{tabular}

\section{Teaching methods}

$\begin{array}{lllll}\text { Qualification for demonstrating skills that are not a part of curriculum } & -1.06 & 2.56 & .80\end{array}$

$\begin{array}{llll}\text { Qualification for demonstrating skills that are a part of the curriculum } & -.61 & 2.99 & .70\end{array}$

$\begin{array}{lllll}\text { Understanding methodical ways in teaching skills that are not a part } & -.58 & 2.60 & .78\end{array}$

of the curriculum

\section{Biological aspects of sport}

\begin{tabular}{llllllll}
\hline Understanding anatomical-functional aspects of sport & -.89 & 3.27 & .62 & & \\
Understanding physiological aspects of sport & -.87 & 3.24 & .63 & & \\
Understanding biomechanical aspects of sport & -.62 & 2.90 & .72 & & \\
Understanding health aspects of PA and sport & -.40 & 3.46 & .56 & .87 & 2.93 \\
Understanding physical and motor development of children and & -.39 & 3.17 & .63 & & \\
youth & -.33 & 3.04 & .75 & & \\
Understanding theory of practising sport & & & & &
\end{tabular}

\section{Communication in foreign language}

\begin{tabular}{llllll} 
Working in international area & .87 & 1.82 & .81 & & \\
Communication in foreign language & .81 & 2.03 & .81 & & 2.33 \\
\hline
\end{tabular}

\section{Social science aspects of sport}

Understanding cultural aspects of sport

$\begin{array}{lll}.74 & 3.21 & .68\end{array}$

Understanding social importance of sport

$\begin{array}{lll}.71 & 3.45 & .61\end{array}$

Understanding philosophical aspects of sport

$\begin{array}{lll}.52 & 2.74 \quad .83\end{array}$

Understanding historical aspects of sport

$\begin{array}{lll}.48 & 2.75 \quad .77\end{array}$

Understanding social circumstances in PE lessons

$\begin{array}{lll}.34 & 3.18 \quad .65\end{array}$

\section{Legis/ation and general educational aspects}

\begin{tabular}{llllll}
\hline Understanding legislation in the area of education & -.61 & 2.39 & .71 & & \\
Understanding school system as a complete entity & -.59 & 2.80 & .73 & & \\
Understanding curricula of different subjects & -.56 & 2.48 & .77 & .77 & 1.92 \\
Qualification for setting goals and learning targets & -.33 & 3.15 & .65 & & \\
\hline
\end{tabular}

\section{Organisation and entrepreneurial spirit}

Ability to take initiative, entrepreneurial spirit

Ability for formation and leading various projects

Ability to connect with external institutions

Organisational skills and knowledge for the implementation of school and extracurricular programmes

$\begin{array}{lllll}-.71 & 2.82 & .86 & & \\ -.61 & 2.99 & .73 & & \\ -.59 & 2.92 & .82 & .81 & 1.45 \\ -.57 & 3.10 & .75 & & \\ \end{array}$

\section{Planning}

\begin{tabular}{llllll}
\hline Qualification for setting goals according to curriculum & -.69 & 3.16 & .70 \\
Understanding general didactics of PE process & -.67 & 3.15 & .65 & \\
Qualification for diagnosing and composing status analysis & -.59 & 3.26 & .63 & \\
$\begin{array}{l}\text { Qualification for planning a process according to status analysis and } \\
\text { curriculum }\end{array}$ & -.58 & 3.05 & .66 & .90 & 1.45 \\
Understanding PE curricula & -.54 & 3.38 & .66 & & \\
Understanding methodical ways in teaching motor skills from the & -.51 & 3.26 & .65 \\
curriculum & & & & \\
Ability to use different teaching methods and forms of teaching PE & -.31 & 3.30 & .60 \\
\hline
\end{tabular}




\begin{tabular}{lllllll}
\hline Factor / Item & I & $\bar{x}$ & $s$ & $\alpha$ & $\% v$ \\
\hline
\end{tabular}

\section{General pedagogic knowledge}

\begin{tabular}{llllll}
\hline Ability for flexible use of knowledge in practical situations & 0.47 & 3.24 & 0.63 & & \\
Ability for recognition, setting and solving problems & 0.42 & 3.13 & 0.59 & & \\
Ability to make right decisions according to the circumstances in a & 0.39 & 3.25 & 0.60 & & \\
lesson & 0.38 & 3.29 & 0.59 & & \\
Ability to lead the team & 0.37 & 3.19 & 0.65 \\
Ability for adaptation and work in new situations & 0.36 & 3.07 & 0.62 \\
Ability for teamwork & & & \\
\hline
\end{tabular}

\section{Ethical aspects}

\begin{tabular}{llllll}
\hline Ability for socially responsible behaviour & .67 & 3.31 & .68 & \\
Appreciation and respect for multiculturalism & .63 & 3.47 & .65 & & \\
Ethical and professionally correct attitude & .63 & 3.38 & .63 & & \\
Considering safety principles in pedagogic process & .56 & 3.18 & .65 & & 1.17 \\
Importance of equal opportunities & .46 & 3.21 & .69 & & \\
Ability for criticism and self-criticism & .41 & 3.20 & .62 & \\
\hline
\end{tabular}

\section{Research work and general educational aspects}

\begin{tabular}{lllllll}
\hline Qualification to research at an appropriate level & .46 & 2.30 & .78 & & \\
Understanding characteristics of research work & .43 & 2.54 & .71 & & \\
Understanding various didactic principles & .36 & 2.93 & .66 & .78 & 1.17 \\
Ability for abstract thinking, analysis and synthesis & .34 & 2.93 & .71 & & \\
Use of ICT & .31 & 2.58 & .73 & & \\
\hline
\end{tabular}

\section{Psycho-pedagogic context of educational process}

\begin{tabular}{llllll}
\hline Understanding psychological aspects of sport & -.46 & 3.13 & .69 & \\
Understanding how to use different pedagogic strategies & -.46 & 2.98 & .66 & .77 & .79 \\
$\begin{array}{l}\text { Understanding different pedagogic approaches and social contexts } \\
\text { when teaching PE }\end{array}$ & -.35 & 2.87 & .68 & & \\
\hline
\end{tabular}

\section{Financial flow and media in sport}

\begin{tabular}{llllll}
\hline Understanding financial flow in sport & .44 & 2.37 & .80 & .77 & .68 \\
Understanding media influence on sport & .35 & 2.82 & .77 & & \\
\hline
\end{tabular}

Note. $\mathrm{x}=$ average value, $\mathrm{s}=$ standard deviation, $\mathrm{I}=$ factor loadings, $\alpha=$ Cronbach's Alpha, $\%$ $v=$ proportion of the total variance (before rotation).

\section{Discussion}

The main finding of the study is that 13 extracted factors (Table 1) indicate a quite complex competence profile of Italian PE teachers. The complexity of estimations of their competences has undoubtedly been influenced by some historical events, which have defined both the contents and the etymological categorisation of PE in Italy (Carraro, Bertollo, Lanza, \& Zocca, 2003; Vitali \& Spoltore, 2010) as well as a late response to the Bologna reforms. For instance, only in 1998 
did Italy found faculties of sports and motor sciences, which replaced a three-year course of study at former higher schools for PE (Istituto Superiore di Educazione fisica) (Mussino et al., 2005). This study also showed that PE teachers could critically evaluate their own perceived level of and, at times, lack of competences.

Specific pedagogic and didactic knowledge is one of the most valuable competences for teachers (Eurydice, 2003), including PE teachers (Campos Mesa, Ries, \& Del Castillo, 2011; Kovač et al., 2008; Romero Cerezo, 2009; Romero Granados \& Campos Mesa, 2010). Italian PE teachers also highly valued their own pedagogic and didactic knowledge, while the first factor in the present research, Didactic approaches, explained $31.3 \%$ of the total variance. It is formed by specific competences, particularly of the instrumental type, related to special pedagogic and didactic approaches in PE lessons, such as creativity in teaching $(\mathrm{l}=.59 ; \overline{\mathrm{x}}=2.96)$ and encouraging the ability of students to solve motor tasks $(\mathrm{l}=.58 ; \overline{\mathrm{x}}=3.11)$. Creativity as an essential competence of future graduates has been mentioned by both the students of the first three years of Spanish sports faculties (Romero Cerezo, Zagalaz Sànchez, Romero Rodriguez, \& Martinez Lòpez, 2011) and Spanish university teachers (Sàenz-Lòpez Bunuel et al., 2009). Vitali and Spoltore (2010) determined that the ability to solve tasks in new and creative ways was vital for Italian teachers. The first factor is also saturated by competences for motivating students to spend their free time more actively $(l=.55 ; \overline{\mathrm{x}}=3.21)$, to encourage their personal progress $(\mathrm{l}=.45 ; \overline{\mathrm{x}}=3.17)$ and to offer help when learning new motor skills. Nowadays, children and youth spend their free time mainly in a sedentary way (Starc \& Strel, 2012). It is known that PA acts as a prevention strategy for health-related problems and establishing PA as a habitual behaviour in children can result in active adult lifestyle (Pate, Baranowski, Dowda, \& Trost, 1996). Italian PE teachers perceive their ability to motivate students for PA quite highly. This is extremely important because the data about the lifestyles of Italian children are alarming: $22 \%$ of 8 - and 9-year-old children are physically active during their free time less than one hour per week, $38 \%$ of them watch television or play videogames more than three hours per day, and only $25 \%$ of them walk or cycle to school (Gargiulo et al., 2015).

The second factor, Teaching methods, includes a group of subject-specific competences, which are generally instrumental and are important in the narrow sense of teaching $\mathrm{PE}$, mostly in demonstration skills as the most important teaching method in the PE process. Italian PE teachers perceive high competence in the good demonstration of the skills that are a part of the curriculum $(\overline{\mathrm{x}}=2.99)$. In contrast, the understanding of the methodical ways in teaching sports contents that are not a part of the curriculum is placed third from the bottom on a list of self-perceived subject-specific competences $(\overline{\mathrm{x}}=2.60)$. This 
finding is disturbing, as new sports that are interesting for young people are constantly appearing (e.g., rollerblading, new forms of modern dance and aerobics, etc.). PE teachers should include these contents in regular PE sessions, as only thus can they follow the interest of young people, which requires adequate demonstration and understanding of methodical ways of including such contents into the educational process. One of the key problems of PE today is the excessive inclusion of traditional content, which is not particularly related to sports that young people practice in their free time (Hardman, 2008). The sample of subjects includes $69.8 \%$ of PE teachers with more than 20 years of work experience, and it is understandable that teachers are hesitant regarding innovations and learning new skills due to numerous injuries among older PE teachers (Lemoyne, Laurencelle, Lirette, \& Trudeau, 2007).

The third factor, Biological aspects of sport, includes a group of subjectspecific instrumental competences, as the items are closely related with the basic professional knowledge in the area of $\mathrm{PE}$, such as anatomical-functional, physiological, biomechanical and health aspects of sport. Many authors consider these factors to be a theoretical background to PE teachers' work and a basis for an efficient PE process (Campos Mesa et al., 2011; Kovač et al., 2008; McKenzie \& Lounsbery, 2013; Romero Granados \& Campos Mesa, 2010; Vitali \& Spoltore, 2010). Within the public health context, PE can play a significant role in reducing sedentary behaviour and contributing to public health (McKenzie \& Lounsbery, 2013).

Italian PE teachers have placed their understanding of health aspects of PA and sport in the first place among subject-specific competences $(\overline{\mathrm{x}}=3.46)$. McKenzie and Lounsbery (2013) believe that the survival of PE programmes in schools will depend largely on how effective PE teachers are in operating within a public health context.

The fourth factor, Communication skills in foreign languages, includes general competences of a mostly instrumental type. The perception of the actual level of communication in foreign languages $(\overline{\mathrm{x}}=2.03)$ and working internationally $(\overline{\mathrm{x}}=1.82)$ are at last and second last places, respectively, on the list of competences, indicating that Italian PE teachers do not feel sufficiently competent in this field. Gianferrari (2009) stated that the ability of Italian primary and secondary school teachers to communicate in a foreign language is poor, regardless of the subject they teach. Similarly, the use of foreign language has been marked below average among Slovenian PE teachers, who also did not wish to improve this type of knowledge (Kovač et al., 2008). Lesser importance and knowledge of written and oral expression in at least one foreign language was also found by Pazo Haro and Tejada Mora (2012) as well as by Sàenz-Lòpez 
Bunuel et al. (2009) in the studies on a sample of Spanish university teachers and postgraduate students, which is unusual as English is a basic communication language in research. Knowledge (and the use) of foreign language in pedagogic practice is a complex problem, related to the age and the length of employment; younger generations tend to have considerably fewer problems in the use of foreign language (Kovač et al., 2008; Vitali \& Spoltore, 2010).

The fifth factor, Social science aspects of sport, exclusively includes subject-specific competences of an instrumental type. Italian teachers perceive themselves to be sufficiently competent in the area of cultural aspects $(\overline{\mathrm{x}}=3.21)$ and the understanding of the social importance of sport $(\overline{\mathrm{x}}=3.45)$. This has also been confirmed by Vitali and Spoltore (2010), who found that belief in the high social significance of sports experts is high among Italian PE teachers.

The sixth factor, Legislation and general educational aspects, includes systemic competences that are related to the knowledge of school legislation as a whole and curricula of individual subjects. Teachers perceived lower competences in these areas, presumably because they cannot directly influence these factors.

The seventh factor includes competences related to the organisational abilities of PE teachers. Findings from numerous studies (ANECA, 2004; Kovač et al., 2008; Romero Cerezo, 2009; Romero Cerezo et al., 2011; Romero Granados \& Campos Mesa, 2010) indicate the importance of possessing competences related to the ability to plan, organise, manage, and lead school and out-of-school sport activities. Italian PE teachers perceive lower competence in this area, as the item related to initiative and entrepreneurial spirit is the tenth worst marked competence $(\overline{\mathrm{x}}=2.82)$, despite the fact that almost one half of PE teachers are regularly included in the school projects or participate in sports activities, also outside of school. Lesser abilities related to the organisation and management of Italian teachers have also been reported by Vannini and Mantovani (2007), whereas Slovenian PE teachers emphasise the need for additional knowledge in this area (Kovač et al., 2008). Entrepreneurial spirit and initiative have been explicitly supported by the EU as the priority tasks of future education by encouraging partnerships between the private sector and various levels of education with the aim of acquiring competences required in the job market (European Commission, 2015; Eurydice, 2003).

The eighth factor, Planning, is defined with subject-specific competences of an instrumental type representing basic professional knowledge in the $\mathrm{PE}$ field (ANECA, 2004; Campos Mesa et al., 2011; Romero Cerezo, 2009; Romero Cerezo et al., 2011; Romero Granados \& Campos Mesa, 2010).

In all items, Italian PE teachers evaluated their range of competences with scores between 3.05 and 3.38. Particularly accentuated was understanding 
the PE curriculum (third highest self-perceived competence).

The ninth factor, General pedagogic knowledge and the flexibility of teacher's work, is represented with general competences of a systemic type. Italian PE teachers consider themselves to be highly competent in their ability to lead a team $(\overline{\mathrm{x}}=3.29)$, ability to make right decisions according to the circumstances in a lesson $(\overline{\mathrm{x}}=3.25)$, and the flexible use of knowledge in practical situations $(\bar{x}=3.24)$. The highest expressed items in this group indicate a certain level of adaptability of Italian PE teachers. Nowadays, teamwork is one of the most important general competences for graduates from different professional profiles (ANECA, 2004; Pazo Haro \& Tajada Mora, 2012; Vitali \& Spoltore, 2010). This ability has also been attributed high importance by PE teachers (Kovač et al., 2008; Romero Cerezo et al., 2011), who simultaneously desire additional knowledge (Kovač et al., 2008) in this area, which includes the competence for successful team-leading. As this has been placed in the context of general competences, it could be concluded that this ability is particularly highly developed among Italian PE teachers.

The tenth factor, Ethical aspects, consists of the group of general competences of a mostly systemic type, which are related to ethics, multiculturality, criticism and self-criticism, and responsible behaviour in a relationship between pupils and teachers as well as on a general societal level. The item about safety in lessons can be understood as an expression of responsible behaviour and thus ethical attitudes towards the pupils.

Ethnicity in Italy is highly relevant, as the population in some areas is significantly multicultural with the number of immigrants increasing each year. According to the latest data, $8.7 \%(\mathrm{~N}=635.195)$ of children in Italy are of different ethnic origin than Italian (Ministero dell'Istruzione, dell'Università $\mathrm{e}$ della Ricerca, 2013). Migrant children are more likely to experience behavioural problems than their non-migrant peers are (Kouider, Koglin, \& Petermann, 2014) due to social exclusion; moreover, their underprivileged position can also influence their physical development and health. In view of the guidelines for working in ethnically mixed environments and the encouragement of respect for interculturality (European Commission, 2015), PA and sport can play an important role in integrating migrant children into new social settings. Due to their rich experiences with migrant children Italian PE teachers feel sufficiently competent in this field: they placed their competences level on the first (multiculturality; $\overline{\mathrm{x}}=3.47$ ), the second (ethical and professionally correct attitude; $\overline{\mathrm{X}}=3.38$ ) and the third positions (socially responsible behaviour; $\overline{\mathrm{x}}=3.31$ ) among the general competences.

The eleventh factor, Research work and general educational aspects, 
included a group of general competences of instrumental and systemic types. In this area, Italian PE teachers do not show particular competence, as the understanding of the characteristics of research work $(\mathrm{x}=2.54)$ and the qualification for such work $(\overline{\mathrm{x}}=2.30)$ were marked relatively low. Due to the historical role of so-called 'educazione fisica' (PE) (i.e., that it was focussed solely on practice), research activity understandably does not have a tradition among Italian teachers (Vitali \& Spoltore, 2010). The use of ICT is one of the weakest points of European teachers, as they seldom include it in their lessons (Eurydice, 2011), presumably also due to the insufficient knowledge for its effective use. This item has been particularly observed in the present study, as the use of ICT was the seventh-lowest marked competence $(\overline{\mathrm{x}}=2.58)$. Similar findings were revealed in the study by Gianferrari (2009) on a sample of beginning teachers and in the study by Turri and Ceccato (2009) on a smaller sample of PE teachers. As the correlation between the ability of teachers for ICT use and their age has been confirmed in other studies (Gianferrari, 2009), the results can be explained by the age of teachers included in the present study. Additionally, the inadequate or out-of-date technology available to teachers could represent a significant reason (Farinelli, 2010; Gianferrari, 2010).

The last two factors explain less than $1 \%$ of the variance. The twelfth factor includes competences related to the psycho-pedagogic contexts of lessons (understanding psychological aspects of sport; understanding various pedagogic strategies of management and pedagogic approaches as well as the social contexts of lessons) and is in its contents correlated with the ninth factor about general pedagogic knowledge. The thirteenth factor is defined by items about the understanding of financial flow in sport $(\overline{\mathrm{x}}=2.37)$ and the influence of media on sport $(\overline{\mathrm{x}}=2.82)$; in both items, teachers perceive their low levels of competence.

\section{Conclusion}

Since teaching is much more than a task and involves values or assumptions concerning education, learning, and society, the concept of teacher competences may resonate differently in different national contexts (European Commission, 2013, p. 8). The present study is the first scientifically designed attempt to form a more precise definition of the perceived competences of the Italian PE teachers.

Italian PE teachers marked their competences highly in the understanding of biological-health rules of development in children and pedagogic-didactic aspects of teaching as well as good communication. Simultaneously, the 
social aspects of sport, multiculturality, safety, and ethics, and the adaptability of their pedagogic ideas are in the forefront, whereas their estimations about communication in foreign language, scientific research work, philosophical and historical aspects of sport and the effects of financial flow on sport are rated with lower scores. Italian PE teachers are orientated towards the presentation of their motor skills and not in the use of ICT technology. Nevertheless, due to the longer professional careers of teachers, they are probably not aware that the use of ICT could efficiently replace their demonstrations and reduce the number of potential injuries, which increase with age (Lemoyne et al., 2007). Low evaluation of the ability to demonstrate and understand the teaching methods of the contents that are not part of the curriculum indicates that Italian PE teachers offer young people mostly traditional sports and not those in which teenagers participate in their free time.

When interpreting the results and defining the contents of individual factors, a certain degree of care is required, mainly because of the different levels of reliability of individual factors and also due to the different degrees of expression of individual items. Furthermore, it should be mentioned that only teachers from the north-eastern part of Italy were included in the study. Care is also required when comparing the findings of this study with similar foreign studies, as different research and methodological approaches should be considered as well as specific social contexts, which formed a basis for individual study.

The expectations for teachers and schools in Europe are changing (Peklaj, 2015): teachers are asked to teach in increasingly multicultural classrooms, to integrate students with special needs, to use ICT for teaching effectively, to engage in evaluation and accountability processes, and to involve parents in schools (OECD, 2009). In some of these areas, Italian PE teachers feel insufficiently competent. Furthermore, as noted in the European Commission's (2012) communique 'Rethinking Education', the reform of education and training systems is essential in achieving higher productivity and the supply of highly skilled teachers with creative thinking that the $21^{\text {st }}$-century marketplace requires. Therefore, they are in need, also in Italy, of (re)evaluation of the quality of teacher preparation programmes for becoming a high-quality teacher (Floden, Richmond, Drake, \& Petchauer, 2017) and a creative system of permanent professional training. From the point of view of the Italian Ministry of Education, which support the improvement of teacher's competences for more qualitative approaches with financial resources ( $€_{500}$ for each teacher per year), a sophisticated system of lifelong professional training should be designed, which will equip teachers with tools to make lessons more efficient (Peklaj, 2015), to allow them to use modern approaches to teaching, to 
adequately differentiate goals and thus bring PE with modern sports contents to various target groups of pupils in more interesting ways.

We have suggested that national professional association of PE teachers prepare web pages with guidelines and examples of good productive learning activities to show how teachers could improve their practice (Floden et al., 2017).

If these recommendations are taken into consideration, they will further enable Italian PE teachers to improve their own range of competences, especially those that have been highlighted as needing improvement.

\section{References}

ANECA (Agencia nacional de evaluacion de la calidad y acreditation) (2004). Propuesta de Titulo de Grado En Ciencas de la Actividad Fisica y del Deporte. [Proposal for the title of the graduate in the physical activity and sport science]. Retrieved from www.aneca.es/var/media/150296/libroblanco_ deporte_def.pdf

Campos Mesa, M. C., Ries, F., \& Del Castillo, O. (2011). Analisis de las competencias adquiridas $\mathrm{y}$ utilizadas por los ERINO agresados maestros en educaciòn Fisica [Analisys of the competences acquired and used by graduated teachers in physical education]. Revista Internacional de Cencias del Deporte, 24(7), 216-229.

Carraro, A., Bertollo, M., Lanza, M., \& Zocca, E. (2003). Nodi epistemologici nella formazione degli insegnanti di educazione fisica [Epistemological dilemmas in physical education teachers' training]. Formazione \& Insegnamento, Organo ufficiale della SSIS del Veneto, 1/2 - 2003.

Deakin Crick, R. (2008). Pedagogy for citizenship. In F. Oser \& W. Veugelers (Eds.), Getting involved: Global citizenship development and sources of moral values (pp. 31-55). Rotterdam: Sense Publishers. European Commission (2005). Common European principles for teacher competences and qualifications. Retrieved from http://ec.europa.eu/education/policies/2010/doc/principles_en.pdf European Commission (2012). Rethinking education: Investing in skills for better socio-economic outcomes. $\operatorname{COM}(2012) 669 / 3$.

European Commission (2013). Supporting teacher competence development for better learning outcomes. Retrieved from http://ec.europa.eu/education/policy/school/doc/teachercomp_en.pdf European Commission (2015). Education and training. Monitor 2015. Retrieved from http://ec.europa. eu/education/monitor

Eurydice (2002). Key competences - a developing concept in general compulsory education. Brussels: Euryidice.

Eurydice (2003). Defining competences and curriculum. European reference points for the teaching profession. Prepared by Eurydice for study visit (England, April 2003).

Eurydice (2011). Key data on learning and innovation through ICT at school in Europe 2011. Retrieved from http://eacea.ec.europa.eu/education/eurydice/key_data_en.php 
Farinelli, F. (2010). Competenze e opinioni degli insegnanti sull'introduzione delle TIC nella scuola italiana [Teachers' competences and opinions about the introduction of ICT in the Italian school system]. Programma Education, Fondazione Giovanni Agnelli Working paper, 29(3), 1-37. Floden, R. E., Richmond, G., Drake, C., \& Petchauer, E. (2017). How teacher education can elevate teacher quality: Evidence from research. Journal of Teacher Education, 68(4), 360-362. Gallardo, A. M. (2006). Evaluating professional competences for labor placement of the physical education teacher. Electronic Journal of research in Educational Psychology, 10(3), 469-492. Gargiulo, L., Adamo, D., Bologna, E., Iannucci, L., Orsini, S., \& Tinto, A. (2015). Stili di vita non salutari: fumo, eccesso di peso, sedentarietà, consumo di alcol. Qualità della vita in Italia: venti anni di studi attraverso l'indagine Multiscopo dell'Istat [Unhealthy lifestyles: Smoking, excess weight, inactivity, alcohol consumption. Quality of life in Italy: The Istat twenty-year-long survey Multiscopo]. Retrieved from https://www.istat.it/it/archivio/145432

Gianferrari, L. (2009). Profilo professionale e competenze dei docenti neoassunti [Professional profile and skills of newly employed teachers]. Torino: Fondazione Giovanni Agnelli.

Gianferrari, L. (2010). I docenti neo-assunti nella scuola che deve affrontare i mutamenti epocali. [Newly employed teachers in the school system that faces epochal changes]. Torino: Fondazione Giovanni Agnelli.

Gonzales, J., \& Wagenaar, R. (2003). Tuning educational structures in Europe. Final report. Bilbao: Universidad de Deusto.

Hardman, K. (2008). The situation of physical education in schools: An European perspective.

Human Movement, 9(1), 1-14.

Hardman, K., Klein, G., Patriksson, G., Rychtecky, A., \& Da Costa, F. C. (2008). Implementation of the Bologna Process and model curriculum development in physical education. In K. Petry, K., Froberg, A. Madella, \& W. Tokarski, Higher education in sport in Europe. From labour market demand to training supply (pp. 56-79). London, UK: Meyer \& Meyer.

Kouider, E. B., Koglin, U., \& Petermann, F. (2014). Emotional and behavioral problems in migrant children and adolescents in Europe: A systematic review. European Child \& Adolescent Psychiatry, 23(6), 373-391.

Kovač, M., Sloan, S., \& Starc, G. (2008). Competences in physical education teaching: Slovenian teachers' views and future perspectives. European Physical Education Review, 14(3), 299-323. Laporte, W. (1997). The physical education teacher for secondary schools in the EU. Journal of the International Council for Health, Physical Education, Recreation, Sport, and Dance, 3, 43-46.

Lemoyne, J., Laurencelle, L., Lirette, M., \& Trudeau, F. (2007). Occupational health problems and injuries among Quebec's physical educators. Applied Ergonomics, 38(5), 625-634.

McKenzie, T. L., \& Lounsbery, M. A. (2013). Physical education teacher effectiveness in a public health context. Research quarterly for exercise and sport, 84(4), 419-430.

Ministero dell'Istruzione, dell'Università e della Ricerca (2013). Alunni con cittadinanza non italiana. Approfondimenti e analisi [Pupils with non-Italian citizenship. Insights and analysis]. Milano:

Fondazione ISMU. Retrieved from http://hubmiur.pubblica.istruzione.it/alfresco/d/d/workspace/ 
SpacesStore/b8ob747b-7336-4a76-9777-5373cfc7906o/alunni_con_cittadinanza_non_italiana.pdf Mussino, A., Cini, F., \& Talucci, V. (2005). Gli studenti di Scienze motorie tra materialismo e postmaterialismo: un approccio alle professioni sportive [Students of Faculty of Motor/Sport science between materialism and postmaterialism: An approach to sports professions]. Rome: Università La Sapienza.

OECD (2009). Creating effective teaching and learning environments. First results from TALIS. Paris: OECD Publications. Retrieved from http://www.oecd.org/dataoecd/17/51/43023606.pdf Pate, R. R., Baranowski, T. O. M., Dowda, M., \& Trost, S. G. (1996). Tracking of physical activity in young children. Medicine and Science in Sports and Exercise, 28(1), 92-96.

Pazo Haro, C. I., \& Tejada Mora J. (2012). Las competencias profesionales en Educaciòn Fisica [The professional competences in Physical education]. Nuovas tendencias en Educaciòn Fisica, Deporte y Recreatiòn, 22, 5-8.

Peklaj, C. (2015). Teacher competences through the prism of educational research. CEPS Journal, 5(3), 183-204.

Romero Cerezo, C. (2009). Definiciòn de mòdulos y competencias del maestro con menciòn en Educaciòn fisica [Modules and competences of the physical education teacher]. Revista Internacional de Medicina y Ciencas de la Actividad Fisica y el Deporte, 9(34), 179-200.

Cerezo, R., Sanchez, Z., Romero Rodriguez, M. N., \& Martinez Lopez, E. J. (2011). Importancia de las competencias profesionales de los Maestros en Educaciòn Fìsica expresadas por los estudiantes [Importance of the professional competences of the primary teachers in physical education expressed by the students]. Retos. Nuevas tendencias en Educaciòn Fisica, Deporte y Recreaciòn, 19, 62-68. Romero Granados, S., \& Campos Mesa, M. C. (2010). Los egresados de magisterio especialistas de educaciòn fisica y sus competencias [The higher education graduates of physical education teachers and their competences]. Journal of Sport and Health Research, 2(2), 167-182.

Saenz-Lopez Bunuel, P., Carmona Marquez, J., Coronel Llamas, J. M., Funtes-Guerra, J. G., Sierra Robles, A., \& Castillo Viera, E. (2009). La percepciòn de la evoluciòn en las competèncias en el alumnado de màster ed educaciòn fisico-deportiva [The opinion about the evolution in the student skills in the physical education and sports master]. Revista de Ciencias del Deporte, 5(3), 123-135. Starc, G., \& Strel, J. (2012). Influence of the quality implementation of a physical education curriculum on the physical development and physical fitness of children. BMC Public Health, 12. doi: 10.1186/1471-2458-12-61.

Turri, M., \& Ceccato, D. (2009). Gli insegnanti e le TIC nella scuola trentina. Indagine sull'utilizzo e la conoscenza delle tecnologie dell'informazione e della comunicazione [Teachers and ICT in the Trentino school system. Survey on the use and knowledge of information and communication technologies]. Retrieved from http://www.vivoscuola.it/c/document_library/get_file?uuid=fd460266-ao33-4ba2b426-3C471aff9d88\&groupId $=10137$

Vannini, I., \& Mantovani, L. (2007). I giovani insegnanti laureati in Scienza della Formazione primaria. Un' indagine empirica tra gli abilitati del Corso di laurea di Bologna [Young Teachers with a degree in primary education. An empirical survey among the qualified by the degree course of the 
University of Bologna]. Bologna: Università di Bologna.

Vitali, F., \& Spoltore, L. (2010). Da un'esigenza sociale ad una figura professionale: competenze e spazi di occupabilità del laureato in Scienze Motorie [From social needs to professional figure: competences and employability of the graduate in The Sport Science]. Giornale Italiano di Psicologia dello Sport, 8, 32-42.

\section{Biographical note}

Miloš Tul, $\mathrm{PhD}$, is employed as physical education teacher at the State Scientific High school of France Prešeren, Trieste, Italy. He was also teaching at the Faculty of Applied Kinesiology of the University of Primorska, Slovenia as an assistant in the Ball Games courses. His research interests include competences of physical education teachers and physical fitness of young football players.

BOJAN LESKošEK, $\mathrm{PhD}$, is an assistant professor at Department of Natural Sciences, Faculty of Sport, University of Ljubljana where he teaches Statistics and Research Methodology. His scientific research focuses on the application of statistics and methodology in sport sciences, physical fitness and motor skills of children and youth, information and expert systems in sport and performance evaluation in sports.

Marjeta Kovač, PhD, is a full professor at Department of Pedagogic and Didactic, Faculty of Sport, University of Ljubljana where she teaches Didactics of physical education, Practical pedagogical training, Management of school and out-of-school-sport programmes etc. Her scientific research focuses on the field of environmental factors that affect physical activity, physical fitness and motor skills of children and youth, working conditions, health problems and competences of PE teachers and different didactic phenomena. She served as a reviewer in several international scientific journals. 